\title{
Ciências da Religião e Teologia como área autônoma: reconfiguração do debate epistemológico, novos desafios e perspectivas para o estudo das (não) religiões e da(s) espiritualidade(s)
}

\author{
Religious Studies and Theology as an autonomous area: reconfiguration of \\ the epistemological debate, new challenges and perspectives for the study of \\ (no) religions and spirituality(s)
}

Dilaine Soares Sampaio*

\begin{abstract}
Resumo
O objetivo deste artigo é refletir sobre a área de Ciências da Religião e Teologia em seu contexto pós autonomia enquanto área de avaliação da CAPES- Coordenação de Aperfeiçoamento de Pessoal de Nível Superior. Num primeiro momento buscarei atualizar o debate epistemológico que tem longa tradição na Área, mostrando que a tão conhecida discussão acerca dos "duplos s" do termo Ciência(s) da(s) Religião(ões), esgota-se, por um lado, e precisa se reinventar, por outro, ou ainda se recolocar em outros termos que diz respeito à consolidação da área enquanto Ciências da Religião "e" Teologia. Num segundo momento, buscarei pensar acerca de alguns dos desafios que se impõem nesse processo de consolidação, considerando alguns caminhos possíveis, tomando como foco duas questões: a do "objeto" e a das perspectivas teórico-metodológicas. Ensaiarei aqui exercícios propositivos quanto aos movimentos que podemos fazer neste processo de consolidação. Ao final, espero, com esse texto, provocar mais diálogos no âmbito da jovem Área autônoma, e ainda colaborar para aqueles que chegam, pois a experiência em sala de aula e a circulação em eventos diversos, mostram que a Área ainda se revela bastante desconhecida ou incompreendida pelos pares, especialmente se considerarmos a diversidade regional em nosso país.
\end{abstract}

Palavras-chave: Ciências da Religião e Teologia; consolidação; área autônoma.

\begin{abstract}
The objective of this article is to reflect on the area of Religious Studies and Theology in its post autonomy context as an area of evaluation of CAPES - Coordination of Improvement of Higher Level Personnel. In the first moment, I will try to update the epistemological debate that has a long tradition in the Area, showing that the well-known discussion about the "double s" of the term Religious Studies/Science(s) of Religion(s) exhausts, on the one hand, and needs to reinvent itself, on the other, or still needs to reinstate itself in other terms that concerns the consolidation of the area as Religious Studies "and" Theology. In a second moment, I will try to think about some of the challenges that are imposed in this consolidation process, considering possible paths focusing on two issues: the "object" and the theoretical-methodological perspectives. I will try propositional exercises related to the movements that we can make in this consolidation process. In the end, I hope, with this text, to provoke more dialogues within the young Autonomous Area, and still collaborate for those who arrive, as the experience in the classroom and the circulation in events of related fields show that the Area still proves to be quite unknown or misunderstood by the peers, especially if we consider the regional diversity in our parents.
\end{abstract}

Keywords: Religious Studies and Theology; consolidation; autonomous área.

Artigo submetido em 28 de maio de 2019 e aprovado em 23 de agosto de 2019.

* Doutora em Ciência da Religião pela UFJF. Professora da UFPB. País de origem: Brasil. E-mail: dicaufpb@gmail.com 


\section{Introdução}

O VI Colóquio do Grupo de Pesquisa Religião e Cultura, realizado pelo Programa de Pós-graduação em Ciências da Religião da PUC Minas, entre os dias o8 e 10 de agosto de 2018, oportunizou-me fazer uma discussão que há muito ansiava e ainda não havia tido oportunidade. Para além da partilha e da frutífera discussão feita na mesa que dividi com o colega Rudolf von Sinner, esse texto é também uma oportunidade para sistematizar e até mesmo aprofundar o que foi verbalizado, aproveitando ainda as discussões que vieram na sequência de nossa mesa durante outras atividades do evento. Diante da temática que nos foi dada, “Teorias da religião em perspectiva intercultural”, considerei que seria interessante e produtivo pensar o tema a partir do novo lugar que ocupa a Área de estudos no país, com a autonomia enquanto área de avaliação ${ }^{1}$ na CAPES ocorrida em 11 de outubro de 2016, com o nome “Teologia” através da Portaria nº 174/2016 (CAPES, 2016) e, posteriormente, redesignada para a atual nomenclatura Ciências da Religião e Teologia, conforme a Resolução $n^{0}{ }^{0}$, de 04 de abril de 2017 (CAPES, 2017).

A partir disso, este texto está dividido em dois momentos. Num primeiro, buscarei atualizar minimamente o debate epistemológico que tem longa tradição na Área, mostrando que a tão conhecida discussão acerca dos “duplos s" do termo Ciência(s) da(s) Religião(ões), apesar de ter sido fundamental para o crescimento e desenvolvimento epistêmico deste campo de conhecimento, esgota-se, por um lado, uma vez que a autonomização da Área se deu a partir de um debate interno, sendo a opção escolhida "Ciências da Religião"2; e, por outro, precisa se reinventar e se recolocar em outros termos que diz respeito à consolidação da área enquanto Ciências da Religião “e” Teologia.

\footnotetext{
${ }^{1}$ Antes desse processo integrávamos a antiga área Filosofia/Teologia, na condição de Subcomissão Teologia. O histórico desses processos já foi muito bem recuperado nos trabalhos de Flávio Senra $(2015 ; 2016 ; 2017)$, os quais recomendo fortemente a leitura.

${ }^{2}$ A nomenclatura atual da área como "Ciências da Religião e Teologia" é fruto de um debate coletivo interno a Área, construído ao longo de seus anos de existência enquanto um campo de estudos. A culminância dessas reflexões se deu na definição pela atual denominação na assembleia da Associação Nacional de Pós-graduação e Pesquisa em Teologia e Ciências da Religião - ANPTECRE, em 2012. Maior detalhamento sobre este momento pode ser visto no artigo de Flávio Senra (2015) e também na ata da referida reunião.
} 
Num segundo momento, buscarei refletir acerca de alguns dos desafios que se impõem no processo de consolidação das Ciências da Religião e Teologia como área autônoma, pensarei algumas perspectivas e caminhos possíveis tomando como foco duas questões: a do "objeto"3 de investigação e a das perspectivas teórico-metodológicas. Quanto ao nosso "objeto" de estudo, identificado muitas vezes para efeitos de síntese como "fenômeno religioso", chamarei atenção para a necessidade de pensá-lo em sua amplitude, cada vez mais alargada e multifacetada. Já quanto às perspectivas teórico-metodológicas, tentarei pensá-las em três movimentos que na prática são concomitantes: um primeiro, seria direcionado ao âmbito da "casa", "endógeno", de "dentro" para "dentro" da Área, refletindo acerca da necessidade de pensarmos uma nova perspectiva de diálogo entre Ciências da Religião e Teologia que possa contribuir tanto para a consolidação da Área quanto para o fortalecimento da especificidade desse campo de saber. Um segundo, que denomino de "exo-endógeno", seria direcionado "de fora" para "dentro", quando apontarei para a necessidade de aprofundarmos nossos movimentos "antropofágicos" em relação às perspectivas teórico-metodológicas das áreas afins. E um terceiro, de caráter mais "exógeno", ou seja, direcionado de "dentro" da Área para "fora", na medida em que haverá cada vez mais a necessidade de nos colocarmos perante nossos pares, demonstrando que a área de Ciências da Religião e Teologia tem as suas especificidades e oferece, portanto, um olhar distinto. Adianto que esses movimentos precisarão ser lidos em perspectiva performática e não de modo linear, partindo do pressuposto de relatividade dos lugares "dentro" e fora”, uma vez que as categorias são relacionais. Também precisarão ser lidos como movimentos que estão entrelaçados. Trata-se aqui mais de um exercício de sistematização das perspectivas e não de "perspectivar" lugares fixos (VIVEIROS DE CASTRO, 2004; 2005; SILVEIRA, 2017).

\footnotetext{
${ }^{3} \mathrm{~A}$ inserção do termo objeto entre aspas tem como fim chamar atenção para as controvérsias nas Ciências Sociais para o que ficou conhecido como "tradição objetificadora", que nos remete a ideia de uma suposta "objetividade científica" e envolve uma série de outros aspectos (VELHO, 2001, p. 236). Dentre eles, especialmente nos estudos antropológicos, particularmente no âmbito da Antropologia da Religião, questiona-se muito o uso da ideia de que temos um "objeto de investigação", uma vez que lidamos com sujeitos. Entretanto, falar em "objeto de pesquisa", é praticamente um jargão acadêmico, se assim se pode dizer, que permanece presente nos diversos manuais de metodologia da pesquisa. Assim, faço o uso ainda do termo, porque ainda se impõe como referência, mas entre aspas porque minhas reflexões justamente questionam e se afastam dessa "tradição objetificadora". Um texto que traz bem essa reflexão é o de Otávio Velho (1998; 2001; 2007), intitulado O que a religião pode fazer pelas ciências sociais?
} 
Ainda nesse começo de conversa considero importante especificar o meu lugar de fala 4 e as motivações que conduziram este texto. A área de Ciências da Religião e Teologia possui um pouco mais de quatro décadas no Brasil e ao rememorar minha trajetória individual, atinei para o dado de que meu envolvimento com a Área chega a quase metade dos anos de sua existência, pois completa agora dezenove anos. Formalmente, tem quinze, levando em conta toda a minha formação, com especialização, mestrado e doutorado em Ciência da Religião no Programa de Pós-Graduação em Ciência da Religião - PPCIR, da Universidade Federal de Juiz de Fora - UFJF, o primeiro programa da Área em uma Universidade Federal, figurando entre os mais antigos da área de Ciências da Religião e Teologia. Esse tempo de envolvimento me permitiu acompanhar de muito perto a discussão epistemológica que trato aqui, posto que os primeiros livros sobre a temática, no Brasil, remetem ao início de nosso século. Um marco interessante nesse sentido é a obra organizada por Faustino Teixeira, A(s) Ciência(s) da Religião no Brasil: afirmação de uma área acadêmica, a qual reúne diversos capítulos de especialistas da área de Ciências da Religião e Teologia e de áreas afins, fruto de um Seminário realizado na UFJF, ao qual pude assistir 5 muitas das exposições que posteriormente geraram os referidos capítulos. Além disso, enquanto docente, desde o ano de 2012, pude ministrar em alguns semestres a disciplina obrigatória denominada "Ciências das Religiões" no PPGCR-UFPB e, desde o ano de 2010, também pude ministrar o componente curricular de mesmo nome em nossos cursos de Graduação em Ciências das Religiões, tanto na Licenciatura quanto no Bacharelado. Dessa forma, muitas das reflexões aqui partem do espaço de interlocução que se constrói em sala de aula, junto com os/as muitos/as discentes aos quais sou imensamente grata. Estar na coordenação adjunta da área de Ciências da Religião e Teologia, integrando a primeira coordenação de área autônoma, embora seja um lugar recente, tem me instigado e

\footnotetext{
${ }^{4}$ Tomo como referência o trabalho de Djamila Ribeiro (2017), intitulado $O$ que é lugar de fala?, tornando-me tributária de suas reflexões, que me inspiram o exercício constante de autorreflexividade, mas agora de modo distinto.

${ }^{5} \mathrm{Na}$ ocasião era graduanda do Curso de História da UFJF e meu envolvimento com o PPCIR-UFJF se iniciava, no ano 2000, através de uma bolsa de iniciação científica junto da Profa. Dra. Fátima Tavares, antropóloga, na época docente do Programa e hoje vinculada ao Departamento e ao Programa de Antropologia da UFBA.
} 
provocado a pensar ainda mais o lugar da área de Ciências da Religião e Teologia no universo acadêmico. Determinante também é o meu trabalho com religiões historicamente subalternizadas, invisibilizadas, desqualificadas e reprimidas, no caso as religiões afro-brasileiras, o que direciona, em alguma medida o meu olhar para as Ciências das Religiões, e aqui, com seus duplos "s”. Por fim, não menos importante, não discutirei sobre gênero, mas inexoravelmente penso também $a$ partir de uma perspectiva "de" e/ou "do" gênero, como mulher numa área extremamente masculina ${ }^{6}$.

Espero, com esse texto, provocar mais discussões, mais questionamentos, mais diálogos no âmbito da jovem Área autônoma. Almejo ainda colaborar minimante para aqueles que chegam, pois a experiência em sala de aula e a circulação em eventos e fóruns diversos de áreas afins, mostram que as Ciências da Religião e a Teologia, tal como fazemos, ainda se revelam bastante desconhecidas ou incompreendidas pelos pares, especialmente se considerarmos a diversidade regional em nosso país.

\section{Ciência (s) da Religião e Teologia como área autônoma: a necessidade de se reconfigurar o debate epistemológico}

A trajetória da Área no Brasil, considerada em perspectiva conjunta, Ciências da Religião e Teologia bem como os estudos em nível de pós-graduação possui, atualmente, 47 anos, tomando como referência as discussões antecedentes e a criação dos primeiros programas de pós-graduação a partir do início década de

\footnotetext{
${ }^{6}$ A assimetria de gênero é objeto de grande atenção na área de Ciências da Religião e Teologia, sendo inclusive colocada como um dos desafios no Documento de área vigente (CAPES, 2016a). Vale ainda ressaltar que a coordenação anterior, que assume o importante papel de transição (durante os anos de 2016 e 2017) entre o lugar na área mista Filosofia/Teologia e, posteriormente, como ár ea autônoma, foi composta por duas mulheres, além do coordenador de área, Prof. Dr. Flávio Senra. Tivemos a Profa. Dra. Sandra Duarte de Souza, coordenadora adjunta dos Programas Profissionais - vinculada ao Programa de Ciências da Religião da Universidade Metodista de São Paulo - UMESP, uma das referências nos estudos de gênero na Área - e pela Profa. Mary Rute Esperandio, coordenadora adjunta dos Programas Acadêmicos - vinculada ao Programa de Pós-graduação em Teologia, da PUC-PR. Até onde se pôde levantar, a antiga área Filosofia/Teologia não contou com a participação de mulheres.
} 
1970.7 Nesse período não foram poucas as publicações que se dedicaram ao debate epistemológico $^{8}$ e que pensaram a natureza dos estudos de religião, suas especificidades e problemáticas. A obra organizada por Teixeira (2001), aqui já mencionada, marca bem o início de uma maior sistematização do debate. A coleção Repensando a religião, da Editora Paulinas, composta de sete volumes, coordenada pelo saudoso Afonso Maria Ligorio Soares ${ }^{10}$, teve seu primeiro volume publicado em 2005 e o último em 2013. Esse conjunto de obras foi uma contribuição muito valiosa para as discussões epistemológicas na área de Ciências da Religião e Teologia bem como para as relações da Área com as demais disciplinas das Humanidades. Outra obra, mais recente, com as discussões já mais atualizadas é o Compêndio de Ciência da Religião, organizado por Passos e Usarski (2013), a qual se constitui em leitura obrigatória para os que já estão na área e qualquer interessado a enveredar-se pelo tema. Também nessa direção temos o trabalho de Silveira e Moraes Júnior (2017), A dimensão teórica dos Estudos de Religião, no qual buscam fazer uma interessante e profícua atualização da discussão epistemológica e certamente torna-se também mais uma das leituras obrigatórias. Mais recentemente temos a publicação do livro Como estudar as religiões (2018), organizado por Emerson Sena da Silveira, com a participação de

\footnotetext{
${ }^{7}$ Tomo como referência o Programa de Teologia da PUC-Rio, criado em 1972 (PPG TEOLOGIA PUC-Rio, 2019), sendo, portanto, o mais antigo da Área. Em seguida, tivemos o PPG de Ciências da Religião da PUC-SP, em nível de mestrado, em 1978, e o PPG de Ciências da Religião da UMESP, criado em 1979. Outro marco dessa trajetória comum às duas disciplinas e que deve ser rememorado aqui é a criação do Departamento de Ciência da Religião na UFJF, em 1969, incialmente vinculado ao Departamento de Filosofia. Em 1971, tornou-se autônomo, através da resolução 178/71 do CEPE (UFJF, 2011, p. 6). Todavia, logo em sua origem, o Departamento de Ciência da Religião da UFJF sofreu com "o 'cerco' do que havia de mais conservador: 'a ação repressiva advinda de uma 'tradição positivista' imperante nas instituições de ensino superior no País 'avessa à religião e ao seu estudo' (DREHER, 2001, p. 154), aliada estrategicamente(...) a 'setores eclesiais prontos a desqualificar qualquer estudo não teológico e/ou institucionalmente independente da religião" (DREHER, 2001, p. 154; CAMURÇA, 2008, p. 43). Diante disso, o Departamento foi fechado, mesmo possuindo uma turma de Bacharelado em Ciência da Religião em andamento, através de vestibular feito em 1976 (UFJF, 2011, p. 7). Tal situação só foi revertida com a criação do curso de Especialização em Ciência da Religião da UFJF, em 1991, do mestrado em 1993 e do doutorad o em 2000 (CAMURÇA, 2008, p. 43).

${ }^{8}$ Eduardo Cruz (2013, p. 37-47) reflete sobre a própria noção do "estatuto epistemológico da Ciência da Religião".

${ }^{9}$ São eles: $O$ que é Ciência da Religião, de Hans-Jürgen Greschat (2005); O crescimento do cristianismo: um sociólogo reconsidera a história, de Rodney Stark (2006); Constituintes da Ciência da Religião: cinco ensaios em prol de uma disciplina autônoma, de Frank Usarski (2006); O espectro disciplinar da Ciência da Religião, organizado por Frank Usarski (2007); Ciências Socias e Ciências da Religião: polêmicas e interlocuções, de Marcelo Camurça (2008); Uma teoria da religião, de Rodney Stark e William S. Bainbridge (STARK; BAINBRIDGE, 2008) e História das Religiões: perspectivas histórico-comparativa, de Adone Agnolin (2013).

${ }^{10} \mathrm{O}$ professor Afonso Soares era teólogo, filósofo e cientista da religião. Atuou por praticamente 20 anos no Departamento de Ciência da Religião da PUC-SP, chegando à livre-docência. É um nome importantíssimo na área de Ciências da Religião e Teologia, tendo contribuído imensamente para o debate epistemológico e para o diálogo entre as Ciências da Religião e Teologia. Seu nome tamb ém marca os estudos afro-brasileiros na Área, uma vez que se dedicou a Teologia afro-brasileira e a relação da igreja católica com as religiões afro, tanto em seu mestrado quanto em seu doutorado. Seu falecimento em 2016 deixou saudades em todos nós da área de Ciências da Religião e Teologia.
} 
vários especialistas da área de Ciências da Religião e Teologia e áreas afins. Embora a obra tenha como foco principal a dimensão metodológica do estudo das religiões, as discussões de caráter epistemológico se fazem presentes.

Sem querer esgotar aqui a bibliografia produzida, quis apenas destacar um conjunto de obras e autores que se dedicaram fortemente a questão e formaram o que Senra (2016) denominou de uma "religiografia". Para além da bibliografia produzida pelos pesquisadores brasileiros, há uma enorme bibliografia internacional que influenciou e subsidiou a discussão aqui feita, afinal, se em nosso país a Área é recente, não o é em outros lugares do mundo. A história da(s) Ciência(s) da(s) Religião(ões), já bastante bem documentada (USARSKI, 2006, 2013), remete ao século XIX no velho mundo, sendo o uso pioneiro do termo “ciência da religião" tributado a Max Müller, em 1867, e as primeiras cátedras localizadas a partir das três últimas décadas do referido século (USARSKI, 2006, p. 23-25).

Em linhas gerais, destacando os posicionamentos fortes e remetendo aos autores e obras onde tal discussão pode ser visualizada, o debate pode ser sintetizado da seguinte forma: de um lado temos um conjunto de autores que defendem uma "perspectiva unificada" para a Ciência da Religião (CAMURÇA, 2008, p. 51), pensando-a como uma disciplina autônoma. Nesse âmbito, destaca-se a produção alemã, da qual partem muitos autores brasileiros por ela subsidiados, que opera com a ideia de uma "Ciência da Religião", singularizada, entendendo a unicidade do método e do objeto, percebendo a Ciência da Religião como uma ciência no sentido moderno dado ao termo e que advoga a necessidade de uma identidade marcada (GRESCHAT, 2005; HOCK, 2010; USARSKI, 2006, 2007). De outro lado temos a produção italiana, que pluraliza o termo pensando as Ciências das Religiões enquanto um campo disciplinar, aberto e dinâmico, considerando a pluralidade do método e do objeto de investigação, destacando o caráter de autonomia relativa (FILORAMO, PRANDI, 1999; DIX, 2007; CAMURÇA, 2008). Entre os dois extremos, Ciências das Religiões e Ciência da Religião, há um 
conjunto de autores que se colocam nos caminhos intermediários: Ciências da Religião ou Ciência das Religiões, o que já foi bem explicitado por Camurça (2008). Basicamente, o debate em torno do duplo "s" diz respeito a visões diferenciadas de "ciência" e de "religião", ou ainda do fenômeno religioso, bem como se refere a questão do "objeto" e do método.

Não tenho como intuito aqui recuperar todo o debate metateórico, pois embora considere fundamental conhecê-lo, quero justamente propor uma "virada de página”, pois nas bases até então instituídas, mostra-se esgotado em certa medida. Silveira e Moraes Júnior (2017) já apontavam nessa direção. As simpatias ou as antipatias para com o uso ou não uso do duplo "s", com todo o debate epistemológico inerente aos diferentes posicionamentos, parecem ter bem menos relevância com o processo de autonomização, que em sua nomenclatura, fruto de debates coletivos internos à Área, não ficou em nenhum dos dois extremos: o singular ou o plural, mas num lugar intermediário: Ciências da Religião. Além disso, nossa autonomização configurou-se acrescida da Teologia, o que percebo como uma especificidade de nossa trajetória acadêmica no Brasil e uma realidade com a qual devemos trabalhar. Se antes a "autonomia no mundo acadêmico" era um pleito, atualmente ela é um dado, então faz-se necessário virar a página e a partir das discussões feitas, avançar, em direções novas. Não mais relevante mas sem nenhum receio afirmo minha simpatia pelo termo pluralizado e sinto-me confortável em atuar como docente num PPG de duplo "s" ainda que minha formação tenha se dado em outro PPG sem os respectivos "s", no qual também não sentia desconforto, uma vez que a atuação multifacetada permite as muitas combinações e não se restringem a identidade nominal do PPG. Ora, a minha formação/atuação e a de muitos outros colegas da área passa por essa bricolagem pois isso é parte de nossa trajetória enquanto Área. Há colegas com formação teológica atuando em PPGs de Ciência da Religião e vice-versa ${ }^{11}$.

\footnotetext{
${ }^{11}$ Vale observar, conforme apurado e descrito no Documento de área 2016 (CAPES, 2016), que os PPGs em Teologia ainda guardam um perfil mais disciplinar em seu corpo docente, pois são poucos que possuem titulação máxima em outras áreas distintas da Teologia.
} 
Evidentemente, não quero também fazer uma discussão simplesmente ou exclusivamente terminológica e espero que a essa altura haja clareza nisso, uma vez que os termos não são apenas palavras escolhidas aleatoriamente. O que desejo chamar atenção é que a autonomização da área implica a ocupação de um lugar, o tão almejado "lugar" no mundo acadêmico, e ele se fez como "Ciências da Religião e Teologia”. Urge assim a atualização e reconfiguração do debate em outros termos uma vez que a autonomização implica um lugar estabelecido, o que nos faz lembrar da tão conhecida e utilizada discussão acerca da "ciência normal" de Thomas Kuhn (1982). Apenas lembra, mas tal perspectiva não mais se adequa, como bem já recordou Higuet (2017, p. 144), haja vista que vivemos num tempo de "crise generalizada dos paradigmas e não mais na simples sucessão de um paradigma hegemônico a outro". Nos termos de Zygmunt Bauman (2001), podemos pensar na impossibilidade de uma "ciência normal" em tempos de "ciência líquida". Ou, ainda de forma mais provocativa, sob as perspectivas latourianas (LATOUR, 2000), a ciência jamais foi sólida ou segura, sendo esta uma ideia forjada, pois o que temos efetivamente é apenas a "ciência em ação", fazendo-se e refazendo-se constantemente, não se configurando, portanto, num empreendimento acabado.

Em outras palavras, independente de posicionamentos ou preferências, uma forma está posta e é fruto de praticamente meio século de caminhos trilhados e de muitos debates coletivos. Isso posto, vale a questão: mas como reconfigurar o debate? Uma primeira sugestão é passarmos a pensar em termos circulares e moventes, não mais dicotômicos, uma vez que mesmo uma nomenclatura definida para a Área não extingue nem a existência das que existem e são diferentes nem limita as que poderão surgir. Pensar de forma circular nos permite a liberdade da troca, nos permite assumir o caráter plural da área sem incômodos, uma vez que já nascemos antenados com o "espírito de época" (VELHO, 2001) que descompartimenta os lugares de saber.

Assim, embora haja docentes titulados em Ciência(s) da(s) Religião(ões) atuando em PPGs de Teologia, tal número é diminuto, de modo que a interdisciplinaridade no âmbito do corpo docente, não é equitativa entre as duas disciplinas que compõem a Área. 
Proponho que "não gastemos mais tanta tinta" na marcação de posições rígidas entre a ausência e a presença do pluralismo do nome, mas que possamos investir em nossa capacidade performática e transformá-la em nossa força e em nosso caminho de consolidação. Embora ainda se possam ver posicionamentos contrários, não considero mais possível a ousadia da ciência em se afirmar como uma certeza incontestável e se colocar como "o" saber. Perspectivas como as de Bruno Latour já vêm nos ensinando há algumas décadas da impossibilidade da tão famigerada "ciência normal", como já apontei acima. Talvez, em tempos outros, a autonomização nos fizesse pensar que atingimos tal patamar. Bom, ainda se pode, a depender da concepção de ciência que se opera. Mas faço a opção latouriana pela "ciência em ação", pela "ciência que não sabe" em oposição a "ciência que sabe" (Cf. LATOUR, 2000). E ainda, se como já defendeu Otávio Velho, a "religião pode fazer algo pelas ciências sociais" (VELHO, 1998), talvez possa mais ainda pelas Ciência(s) da Religião que se afirma no mundo acadêmico brasileiro junto com a Teologia, a qual se configura também de forma pluralista, como "Teologias", que vem se renovando e se mostrando cada vez mais multifacetada, ganhando vida em nossos horizontes teóricos cada vez menos positivistas (SILVEIRA; MORAES JÚNIOR, 2017, p. 83). No próximo momento, pretendo tornar mais claro como os caminhos de circularidade e movência podem ser construídos nesse momento de pós-conceito, em que precisaremos (des)conceituar para nos recolocarmos em outros termos (SILVEIRA; MORAES JÚNIOR, 2017, p. 92).

\section{Novos desafios, perspectivas e caminhos profícuos para o estudo das (não) religiões e da(s) espiritualidade(s)}

O processo de consolidação da Área exigirá das pessoas que a constroem cotidianamente um "novo" "espírito de movimento", pois precisaremos nos movimentar em direções diferentes, mas que se conectam. Relativizo o termo "novo", recorrendo mais uma vez ao uso das aspas, por entender que o "inteiramente novo" é algo difícil de ser alcançado, pois habitualmente se parte de um caminho já feito, de uma trajetória já construída. Assim, num exercício 
propositivo, penso na possibilidade de três movimentos que denominei como: exógeno, endógeno e exo-endógeno, conforme anunciei no princípio desse texto. Seguindo em meu exercício propositivo, buscarei aqui esclarecer cada movimento.

O primeiro deles, o movimento endógeno, sobre o qual desejo me alongar mais, dada a sua importância, implica em reconhecer cada vez mais o pluralismo e a possibilidade de ampliação de nosso "objeto". Devemos estar cada vez mais atentos a perguntar, enquanto "objeto de investigação", pela não religião, pela não espiritualidade, pela espiritualidade não religiosa, descircunscrevendo assim o "fenômeno religioso". O caminho de descircunscrever a religião, acompanhando suas múltiplas formas de manifestação, nas sutilezas dos "não" lugares religiosos é um exercício que se mostra cada vez mais necessário em tempos acelerados e híbridos ${ }^{12}$.

Quanto ao método, o diálogo com a Teologia pode se dar cada vez mais em outros termos, não mais aprisionado a possíveis tensões, marcações fortes de fronteiras, mas focado no arejamento de ambas, tanto das Ciências da Religião como da Teologia e ainda naquilo que podem trocar, compartilhar e interagir. Nesse contexto, na pluralidade das Teologias e das discussões feitas, são muito bem-vindas perspectivas da Teologia Pública (SINNER, 2016), especialmente os autores que chamam atenção, e não há pouco tempo, para a agenda do pluralismo religioso que precisa ser cumprida por ela, falando em uma "Teologia pública multirreligiosa" (QUERO, 2016). Estudos e pesquisas, já realizados na Área ou em diálogo a partir dela, precisam ser ainda bem mais incentivados como aqueles feitos no âmbito de uma Teologia pós-colonial (CARVALHAES, 2016), de uma Teologia africana e afro-brasileira (BERKENBROCK, 2014; SOARES, 2014) de uma Teologia afro-indígena (RIBEIRO, 2018), de uma Teologia Pluralista ou do Pluralismo religioso (RIBEIRO, 2012, 2012a, 2013, 2018), de uma Teologia queer (MUSSKOPF, 2012), de uma Teologia gay (MUSSKOPF, 2015) e de uma Teologia

\footnotetext{
${ }^{12}$ Híbrido no sentido conferido por Bruno Latour (1994), que desorganiza a maneira moderna de conceber o mundo, quebrando com as dicotomias e pares binários excludentes.
} 
feminista (GEBARA, 2010; ROSADO-NUNES, 2006), dentre novas possibilidades que podem surgir. Vale frisar que tal lista não se esgota porque os desafios não se encerram jamais, contudo, quis apenas indicar movimentos importantes que já se fazem na área, mas que necessitam de receber ainda maior investimento nesse processo.

Com isso, quero evidenciar que, no concernente à consolidação da área de Ciências da Religião e Teologia, a qual exige o estabelecimento de pontes, conexões, pontos de encontro, amadurecimento do diálogo entre as duas disciplinas, entendo que no âmbito das Teologias, em sua pluralidade, não são todas que contribuem para a consolidação, da mesma forma, nos termos que venho tratando. As Teologias que se propõem à maior abertura e inclusão têm mais condições de contribuir com esse processo, uma vez que a produção voltada para dentro ou fechada para a confessionalidade não soma significativamente para a consolidação da Área.

Obviamente, que a via precisa ser de mão dupla e as Ciências da Religião precisam também estar abertas para este movimento que proponho. De modo prático, essas pontes e conexões que sugiro podem ser efetivadas através de dossiês conjuntos em periódicos vinculados tanto aos PPGs de Teologia quanto aos PPGs de Ciência(s) da(s) Religião(ões) ou ainda através dos intercâmbios entre os PPGs de Teologia e Ciências da Religião(ões), nos valendo da condição de professores e professoras visitantes. Tal experiência ainda é pouco feita, pois vemos mais essa troca "intra" cada disciplina que compõe as Ciências da Religião e Teologia e menos "entre" as disciplinas. Não vejo forma de consolidar a jovem Área autônoma sem enfrentarmos os desafios internos a ela, de "peito aberto", passando por todos os desconfortos que qualquer enfrentamento gera. Não se trata de diluir as diferenças entre Ciências da Religião e Teologia, pois tal empreitada seria não só impossível como inútil, pois as distinções sempre existirão, são inerentes à constituição de cada uma e é necessário que existam, mas se trata de estabelecermos frutíferos diálogos. 
Ainda no âmbito do movimento endógeno mas já a caminho do exoendógeno e entrelaçado a ele, não consigo ver a consolidação da Área sem enfrentarmos o problema de sua de(s)colonização $o^{13}$, como bem tratou Cristina Borges durante sua exposição no VI Colóquio do Grupo de Pesquisa Religião e Cultura, aqui já mencionado, e como aborda em um de seus trabalhos (Cf. BORGES, 2014). A área de Ciências da Religião e Teologia dedica a maior parte de seus estudos ao cristianismo, religião hegemônica em nosso país. Tal constatação pode ser feita consultando as áreas de concentração, linhas e projetos de pesquisa disponibilizados nos sites dos vinte e um programas que integram a área 44 Ciências da Religião e Teologia na CAPES. As religiões africanas, afro-brasileiras e indígenas ainda são pouco estudadas na Área. Há apenas cinco Programas, ${ }^{14}$ dentre os vinte e um da área, que possuem docentes que se dedicam ao estudo das religiões afro-brasileiras, ofertando, portanto, disciplinas e orientando discentes de mestrado e/ou doutorado. Já as religiões indígenas são ainda menos estudadas, havendo apenas dois Programas na Área ${ }^{15}$ com docentes dedicados ao tema.

Dar mais atenção a outras religiões não hegemônicas, historicamente invisibilizadas, por si só, não resolveria a questão, pois há a armadilha de tratar essas religiões reificando as mesmas estruturas de opressão às quais foram

\footnotetext{
${ }^{13}$ Neste espaço não terei como aprofundar nem fazer um mapeamento completo da imensa bibliografia que envolve os chamados estudos "pós-coloniais", "de(s)coloniais", "de-coloniais" ou ainda "estudos subalternos". A própria terminologia traz questões teóricas fortes. Embora a discussão ainda careça de grande aprofundamento nas Ciências da Religião e Teologia, o texto de Lauri Wirth (2013), intitulado Religião e epistemologias pós-coloniais, de caráter introdutório, é muito elucidativo tanto para as pessoas que desejam compreender de modo panorâmico as epistemologias pós-coloniais quanto para percebermos as dificuldades que temos de enfrentar nos estudos de religião. Assim, apesar da multiplicidade de termos, tais estudos têm em comum "um esforço teórico múltiplo, historicamente situado e de caráter aberto, não só no sentido de inacabado, mas principalmente por referenciar-se a formas múltiplas de conhecimentos e saberes" (WIRTH, 2013, p. 129). Tais estudos têm ainda em comum o enfrentamento da "colonialidade do poder", nos termos postos por Aníbal Quijano (2010), que de modo sintético seria o seguinte: se o colonialismo é mais antigo e datado historicamente, a colonialidade, vinculada a ele, é um processo mais amplo, mais profundo e mais duradouro do que o colonialismo, pois prevalece até hoje, daí a necessidade do "giro decolonial", ou seja, "um termo cunhado originalmente por Nelson MaldonadoTorres em 2005 e que basicamente significa o movimento de resistência teórico e prático, político e epistemológico, à lógica da modernidade/colonialidade (BALLESTRIN, 2013, p. 105). Para Maldonado-Torres, "a partir de Fanon pode-se chegar à conclusão de que a decolonização é tanto um projeto incompleto e em processo como uma atitude. Com base no exercício da decolonização como projeto e atitude é que qualquer uso de disciplinas e método tem sentido. Do contrário, as disciplinas e os métodos tendem a ser orientados pelo projeto e pela atitude moderno-coloniais" (MALDONADO-TORRES, 2016, p. 93). Assim, é esse tipo de atitude que precisamos levar em conta em nosso movimento endógeno. O autor fala ainda de uma "consciência decolonial" e de uma "transdisciplinaridade decolonial" (MALDONADO-TORRES, 2016, p. 94).

${ }^{14}$ Refiro-me ao Programa de Pós-Graduação em Ciência da Religião da UFJF, ao Programa de Pós-Graduação em Ciências das Religiões da UFPB, ao Programa de Pós-Graduação em Ciências da Religião da UEPA, ao Programa de Pós-Graduação em Ciências da Religião da UFS e ao Programa de Pós-Graduação em Ciências da Religião da UNICAP. Através do site de nossa associação, a ANPTECRE, chega-se rapidamente aos sites dos respectivos programas. Para conferir, acesse: https://www.anptecre.org.br/

${ }^{15}$ Programa de Pós-Graduação em Ciência da Religião da UFJF e ao Programa de Pós-Graduação em Ciências da Religião da UEPA.
} 
submetidas, ou seja, sob a perspectiva da "colonialidade", como trata Quijano (2010), aqui já citado. Isto podemos aprender com as discussões em torno do "giro decolonial" ou ainda as discussões acerca das "epistemologias do sul" (NUNES, 2010). O que considero importante é que os estudos das religiões afro-indígenas são capazes de conduzir aquele/a que o faz para a audição de outras epistemes, que se fazem presentes naquelas vivências religiosas e assim a Área terá condições de contribuir para o fim do epistemicídio ${ }^{16}$ (SANTOS; MENESES, 2010) até então praticado pelo universo acadêmico, marcado pelo eurocentrismo e pelo ocidentalismo.

Quanto ao segundo movimento, o exo-endógeno, para além do já apontado nos entrelaçamentos com o movimento endógeno, recordo que este seria aquele direcionado "de fora" para "dentro" e diz respeito à necessidade de aprofundarmos nossos movimentos "antropofágicos" em relação às áreas afins como já indicaram Silveira e Moraes Júnior (2017). Tal movimento sugere que aprofundemos cada vez mais o exercício de trazer conceitos fortes, teorias e metodologias de áreas afins, fazendo um uso não automático, mas crítico e pensando sua aplicabilidade efetiva para a área de Ciências da Religião e Teologia.

Exemplifico tal movimento com o projeto desenvolvido por Emerson Sena da Silveira como professor visitante no Programa de Ciências das Religiões da UFPB em abril de 2018. Seu projeto intitulado Ciências da religião, perspectivismo ameríndio e hermenêutica: diálogos e interlocuções possíveis, teve como objetivos "propor a leitura do perspectivismo ameríndio de Viveiros de Castro no âmbito das Ciências da Religião e analisar as possibilidades do perspectivismo ameríndio como um método, de cunho hermenêutico, válido para as Ciências da Religião a partir dos confrontos com religiosidades afro-indígena (Jurema)" (SILVEIRA, 2017). Fui

\footnotetext{
${ }^{16}$ Boaventura de Souza Santos entende como epistemicídio o processo de "supressão dos conhecimentos locais perpetrada por um conhecimento alienígena". Assim, "sob o pretexto da 'missão colonizadora', o projeto da colonização procurou homogeneizar o m undo, obliterando as diferenças culturais (SANTOS; MENESES, 2010, p. 16-17). Com isso, desperdiçou-se muita experiência social e reduziu-se a diversidade epistemológica, cultural e política do mundo. Na medida em que sobreviveram, essas experiências e essa diversidade foram submetidas à norma epistemológica dominante (...)" (SANTOS; MENESES, 2010, p. 16-17). A partir do Boaventura Souza Santos, Sueli Carneiro irá tratar, em sua tese de doutoramento, a questão do epistemicídio, conectando-o ao dispositivo de racialidade/biopoder, fazendo-o de modo aprofundado no capítulo três de seu trabalho (CARNEIRO, 2005).
} 
inserida no projeto em virtude do trabalho que desenvolvo com o CatimbóJurema ${ }^{17}$ em João Pessoa e, através da etnografia, percebemos a possibilidade de "perspectivar" o "perspectivismo ameríndio" de Viveiro de Castro (2004, 2015) com o olhar das Ciências das Religiões, realizando assim o exercício da antropofagia, que implica não simplesmente transpor os conceitos e perspectivas de áreas afins, mas de usá-los de forma crítica, digerindo-os e, ao mesmo tempo, pondo para fora aquilo que não dialoga com as especificidades da Área. Esse movimento pode ser mais audacioso e pode se dar cada vez mais com autores/as que não lidam com o fenômeno religioso, mas que mesmo assim têm muito a nos dizer.

Por fim, o que chamo de movimento exógeno seria a necessidade, agora mais forte, de mostrarmos e valorizarmos as nossas especificidades, deixando claro aquilo que podemos e temos a oferecer de inovador. Talvez esse movimento seja o principal ponto de atualização do debate epistemológico dos duplos "s", na (s) Ciência (s) da (s) Religião (ões), pois a perspectiva que defende a ideia de "campo disciplinar" aqui já explicitada, como "estrutura dinâmica e aberta" não pode ser compreendida como ausência de especificidade. Penso que nesse processo de consolidação, demonstrar o olhar distinto e peculiar da área de Ciências da Religião e Teologia se mostra fundamental.

O movimento exógeno deve implicar também o compromisso e a responsabilidade da Área, agora autônoma, com a manutenção e o fortalecimento da democracia e dos direitos humanos num contexto nacional ${ }^{18}$ de instrumentalização da religião para o desenvolvimento de políticas opressoras e supressoras de direitos. Este movimento exógeno deve incluir uma atuação e uma

\footnotetext{
${ }^{17}$ Já tratei do uso unificado do termo em outra oportunidade (SAMPAIO, 2018).

${ }^{18}$ Apesar de haver controvérsias e tais acontecimentos estarem ainda sendo objeto de análise, dada as dificuldades da "História do tempo presente", trago a perspectiva de que em 2016 o Brasil viveu um golpe parlamentar, jurídico e midiático que culminou na retirada da presidenta eleita Dilma Rousseff do governo brasileiro, o que acarretou consequências drásticas no que diz respeito aos direitos da maioria da população. Tal cenário tornou-se ainda mais complexo com as eleições presidenciais realizadas em outubro de 2018, com a subida ao poder de um governo que não só aprofunda as ações do pós-golpe como toma outras medidas ainda mais prejudiciais, especialmente para o campo da educação, das políticas sociais e dos direitos dos trabalhadores. Para saber mais sobre tal contexto, verificar: CNTE (2017); Braz (2017); Souza (2019; 2016).
} 
forte reflexão do papel da Área no atual contexto, no sentido de pensar e mostrar o que cientistas da religião e teólogos têm a contribuir para a sociedade. Silveira e Moraes Júnior já chamaram atenção para isso ao pensarem "o futuro da(s) Ciências (s) da Religião" e incluírem o "papel de protagonistas nos problemas contemporâneos que envolvam a religião em seus múltiplos desdobramentos sociais, culturais e políticos" (SILVEIRA; MORAES JÚNIOR, 2017, p. 121) como uma de nossas grandes agendas. Reforço veementemente essa agenda, ressaltando que este deve ser, na perspectiva aqui pensada, um compromisso da área de Ciências da Religião e Teologia como um todo.

Ora, se o estudo das (não) religiões e espiritualidade (s) não é exclusividade nossa, é em nosso caso o fim em si mesmo, de modo que passamos pelos outros temas para compreender as religiões, diferente dos demais especialistas que fazem um caminho inverso, ou seja, a religião é mais um caminho de passagem para compreender outras questões na sociedade, conforme já recordou Camurça (2008, p.33), citando como exemplo o trabalho da antropóloga Paula Montero (1999). Em um de seus textos bastante conhecidos, intitulado Religiões e dilemas na sociedade brasileira, a autora afirma: "os fenômenos religiosos interessam-me, não como um campo em si mesmo de investigação, mas como via de acesso à compreensão da sociedade brasileira" (MONTERO, 1999, p. 329). Dessa forma, o protagonismo reivindicado por Silveira e Moraes Júnior, aqui reforçado, ganha ainda contornos mais fortes, em tempos de usos e abusos da(s) religião(ões), repaginados pela velocidade da "Era das redes sociais", demonstrando assim que a nossa tarefa se vê bastante ampliada. Considero ainda que este protagonismo envolve posicionamentos e ações diante da sociedade civil, tanto de modo autônomo enquanto área, quanto através de conexões e parcerias com associações científicas das áreas próximas.

Para finalizar essa parte e para efeitos de síntese, considerei que seria interessante buscar traduzir imageticamente os três movimentos aqui propostos no gráfico abaixo: 


\section{Gráfico 1: Consolidação da área de Ciências da Religião e Teologia recém} autonomizada em 3 movimentos

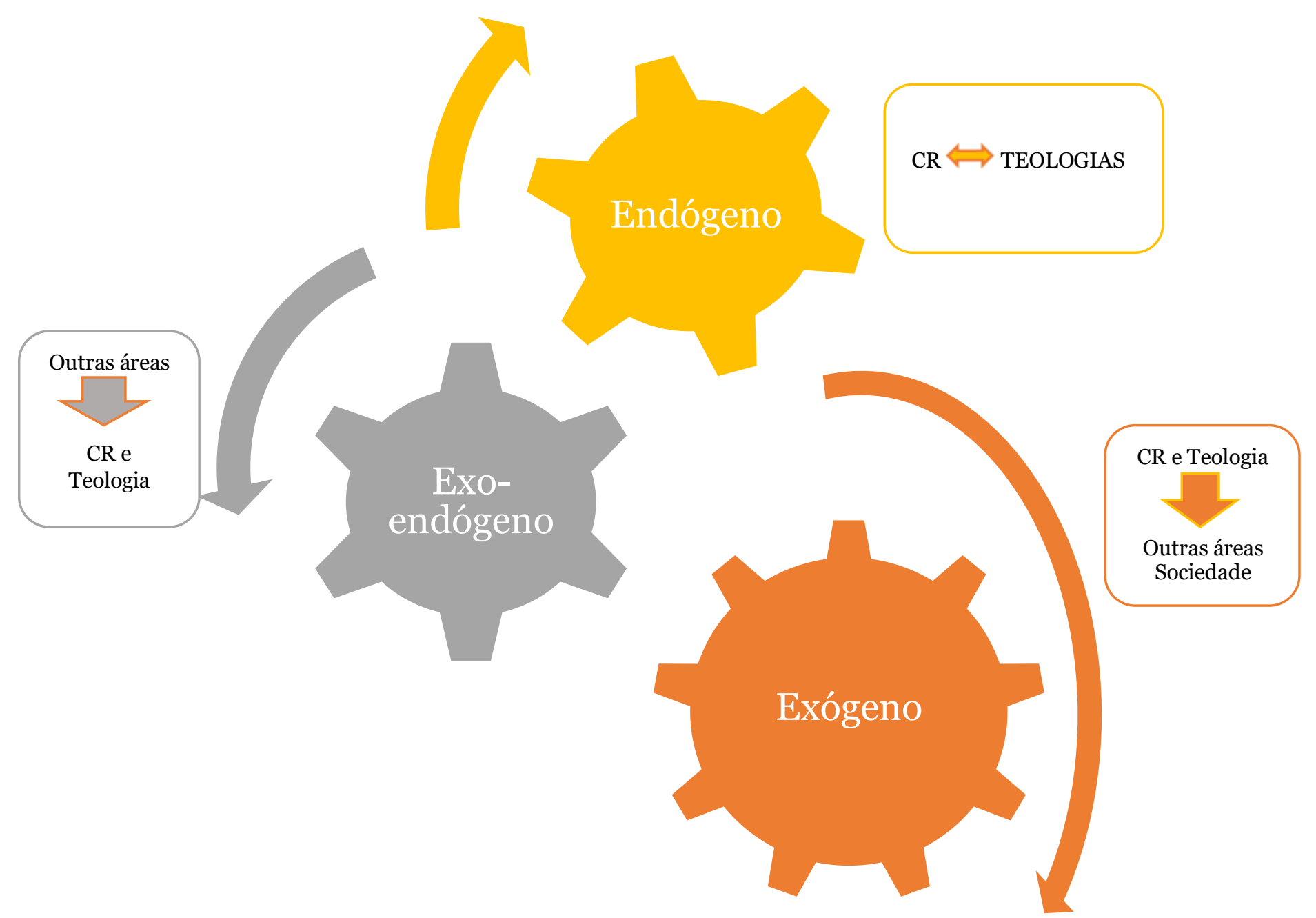

Fonte: Elaborado pela autora. 


\section{Considerações finais}

Busquei, nas linhas acima, refletir sobre o papel, o lugar e as perspectivas possíveis da área de Ciências da Religião e Teologia enquanto área autônoma, retomando o clássico debate epistemológico da área em torno dos duplos "s", mostrando seus limites e a necessidade urgente de reconfigurá-lo em outros termos. Tentei, através de um exercício propositivo, pensar três movimentos para a Área recém autonomizada, que longe de serem movimentos fixos, funcionaram mais como uma plataforma de trabalho, para reflexão e ações possíveis ou ainda aprofundamento daquilo que já fazemos.

A partir de Silveira e Moraes Júnior (2017), podemos dizer que grande parte da "má vontade" de muitos de nossos pares advém de uma compreensão limitada de ciência, ainda apegada aos pressupostos positivistas, à disputa travada com o advento da modernidade entre o saber científico e o religioso. Por vezes o saber científico se quer essencialista ou até mesmo ganha contornos fundamentalistas. A área de Ciências da Religião e Teologia tem o privilégio, agora em lugar "legitimamente" reconhecido, de protagonizar novas formas de construção do saber. Podemos nos revestir de um "espírito de vanguarda" e buscarmos nos diálogos que certamente serão aprofundados na Área, uma "sensibilidade epistêmica" que seja capaz de operar com outras epistemologias, especialmente aquelas marcadas pela decolonialidade.

Assim, em vez de "gastarmos mais tinta" para discutir sobre o "estatuto epistemológico das CR”, como já mostrei, num outro horizonte é possível construir a pinceladas, como se preenche uma tela, uma "epistemologia sensível" para a jovem área autônoma, que será forjada na "encruza" (SIMAS; RUFINO, 2018) não só das Ciências da Religião com a(s) Teologia(s) e os saberes acadêmicos, mas também com os outros saberes advindos de nossos sujeitos, que são saberes encantados, tradicionais, populares, para além dos cruzamentos que já operamos, dado ao nosso caráter inter, multi e transdisciplinar. 
Que possamos ser capazes de construir uma epistemologia "de" e "na" "encruzilhada", nos sentidos atribuídos pelas epistemologias africanas e afrobrasileiras, para os estudos da(s) (não) religião(ões) e da(s) (não) espiritualidade(s), uma epistemologia sensível que saiba afetar e deixar-se afetar (VELHO, 2001) pelos saberes outros. Que possamos ter a sabedoria da circularidade, mas também da dialética, aprendendo a dançar entre os saberes provenientes de nossos sujeitos de pesquisa e o (des)encanto dos saberes científicos.

\section{REFERÊNCIAS}

AGNOLIN, Adone. História das religiões: perspectiva histórico-comparativa. São Paulo: Paulinas, 2013.

ASAD, Talal. Genealogies of religion: discipline and reasons of power in Christianity and Islam. Baltimore; London: The Johns Hopkins University Press, 1993.

ASSOCIAÇÃO NACIONAL DE PÓS-GRADUAÇÃO E PESQUISA EM TEOLOGIA E CIÊNCIAS DA RELIGIÃO. Ata da reunião realizada no dia 08 de maio de 2012.

BALLESTRIN, Luciana. América Latina e o giro decolonial. Revista Brasileira de Ciência Política, Brasília, n. 11, p. 89-117, maio-ago. 2013.

BAUMAN, Zygmunt. Modernidade líquida. Rio de Janeiro: Zahar, 2001.

BERKENBROCK, Volney. A teologia como sabedoria iniciática: elementos para uma teologia fundamental afro-brasileira. In: OLIVEIRA, Irene Dias de; JORGE, Érika. Teologia afro-brasileira. São Paulo: Arché Editora, 2014. p. 17-40.

BORGES, Cristina. Religião e Epistemologias pós-coloniais: um pensar na liminaridade afro-sertaneja. In: $\mathbf{2 7}^{\mathbf{0}}$ Congresso Internacional da SOTER. Espiritualidades e dinâmicas sociais: memórias-prospectivas. Belo Horizonte: SOTER, 2014. v. 1. p. 15671580 .

BRAZ, Marcelo. O golpe nas ilusões democráticas e a ascensão do conservadorismo reacionário. Serviço Social \& Sociedade, São Paulo, n. 128, p. 85-103, abr. 2017. Disponível em: http://www.scielo.br/scielo.php?script=sci_arttext\&pid=So10166282017000100085\&lng=en\&nrm=iso. Acesso em: 09 mar. 2019. 
CAMURÇA, Marcelo. Ciências sociais e ciência das religiões: polêmicas e interlocuções. São Paulo: Paulinas, 2008.

CARNEIRO, Aparecida Sueli. A construção do outro como não-ser como fundamento do ser. 2005. Tese (Doutorado em Educação) - Universidade de São Paulo, São Paulo, 2005.

CARVALHAES, Jorge. Teologia pública e pós-colonialismo. In: SINNER, Rudolf von; PANOTTO, Nicolás (org.). Teología pública: un debate a partir da América Latina. São Leopoldo: Faculdades EST, 2016. p. 27-36.

CARVALHO, José Jorge. O encontro de velhas e novas religiões: esboço de uma teoria dos estilos de espiritualidade. In: MOREIRA, Alberto; ZICMAN, Renée (org.). Misticismo e novas religiões. Petrópolis, RJ: Vozes; Bragança Paulista, SP: Instituto Franciscano de Antropologia da Universidade de São Paulo, 1994.

CHAMPION, Françoise. Religiosidade flutuante, ecletismo e sincretismos. In: DELUMEAU, Jean. As grandes religiões do mundo. Lisboa: Editorial Presença, 1997.

CNTE - Confederação Nacional dos Trabalhadores em Educação. 2016: o Brasil esfacelado pelo golpe. Brasília: CNTE, 2017.

COORDENAÇÃO DE APERFEIÇOAMENTO DE PESSOAL DE NÍVEL SUPERIOR CAPES. Documento de área 2017. Área Teologia. Brasília, 22 nov. 2016a.

COORDENAÇÃO DE APERFEIÇOAMENTO DE PESSOAL DE NÍVEL SUPERIOR CAPES. Portaria 174, de 11 de outubro de 2016. Diário Oficial da União, Brasília, 13 out. 2016.

COORDENAÇÃO DE APERFEIÇOAMENTO DE PESSOAL DE NÍVEL SUPERIORCAPES. Resolução no 1, de 04 de abril de 2017. Boletim de Serviço/CAPES, Brasília. Edição Especial n⿳0 1, abr. 2017.

CRUZ, Eduardo R. Estatuto epistemológico da Ciência da Religião. In: PASSOS, J. D.; USARSKI, F. (org.). Compêndio de Ciência da Religião. São Paulo: Paulinas: Paulus, 2013. p. 37-47.

DIAS, Zwinglio Motta. Teologia pública - uma proposta. Disponível em: http://koinonia.org.br/periodicos/theologia-publica/teologia-publica-umaproposta/4049. Acesso em: 05 ago. 2018.

DIX, Steffen. O que significa o estudo das religiões: uma ciência monolítica ou interdisciplinar? Working Papers. Instituto de Ciências Sociais (Universidade de Lisboa), p. 2-28, 2007. Disponível em:

http://www.ics.ul.pt/publicacoes/workingpapers/wp2007/wp2007_1.pdf. Acesso em: 10 mai. 2012. 
DREHER, Luís Henrique. Ciência(s) da Religião: teoria e pós-graduação no Brasil. In: TEIXEIRA, Faustino. A(s) Ciênci (s) da Religião no Brasil: afirmação de uma área acadêmica. São Paulo: Paulinas, 2001. p. 151- 178.

ELIADE, Mircea. Origens: história e sentido na religião. Lisboa. Edições 70, 1990.

FACULDADES EST. Conheça a Faculdades EST. História. Disponível em: http://www.est.edu.br/conheca-a-est/historia. Acesso em: 19 mar. 2019.

FACULDADES EST. Graduação. Bacharelado em Teologia. Apresentação. Disponível em: http://www.est.edu.br/graduacao/bacharelado-em-teologia/. Acesso em: 19 mar. 2019a.

FILORAMO, Giovanni; PRANDI, Carlo. As Ciências das Religiões. São Paulo: Paulus, 1999.

GEBARA, Ivone. Vulnerabilidade, justiça e feminismos. São Bernardo do Campo: Nhaduti Editora, 2010.

GONÇALVES, Alonso. Teologia pública: entre a construção e a possibilidade prática de um discurso. Ciberteologia: revista de teologia \& cultura, ano 8, n. 38, p. 63-76, abr.-jun. 2012.

GRESCHAT, Hans-Jürgen. O que é Ciência da Religião? São Paulo: Paulinas, 2005.

HANEGRAAFF, Wouter J. Definindo religião, apesar da história (Tradução de Fábio L. Stern). Religare, Paraíba, v. 14, n. 1, p. 202-247, 2017. Disponível em:

http://www.periodicos.ufpb.br/ojs/index.php/religare/article/view/37583. Acesso em: 20 ago. 2018.

HANEGRAAFF, Wouter J. Defining religion in spite of History. In: PLATVOET, Jan G.; MOLENDIJK, Arie L. (org.). The pragmatics of defining religion: contexts, concepts and contests. Leiden: Brill, 1999. p. 337-378.

HANEGRAAFF, Wouter. Espiritualidades da Nova Era como uma religião secular: perspectiva de um historiador (Tradução de Fábio L. Stern). Religare, Paraíba, v. 14, n. 2, p. 403-424, dez. 2017. Disponível em:

https://periodicos.ufpb.br/ojs/index.php/religare/article/view/37587. Acesso em: 20 ago. 2018.

HANEGRAAFF, Wouter. New Age spiritualities as secular religion: a historian's perspective. Social Compass, v. 46, n. 2, p. 145-160, 1999.

HIGUET, Etienne Alfred. Posfácio. In: SILVEIRA, Emerson Sena da; MORAES JÚNIOR, Manoel Ribeiro. A dimensão teórica dos Estudos da Religião: horizontes histórico, epistemológico e metodológico nas Ciências da Religião. São Paulo: Fonte Editorial, 2017. p. 141-149.

HOCK, Klaus. Introdução à Ciência da Religião. São Paulo: Loyola, 2010. 
KUHN, Thomas S. A estrutura das revoluções científicas. São Paulo: Perspectiva, 1982.

LATOUR, Bruno. Ciência em ação: como seguir cientistas e engenheiros sociedade afora. São Paulo: UNESP, 2000.

LATOUR, Bruno. Jamais fomos modernos: ensaio de uma antropologia simétrica. Rido de Janeiro: Editora 34, 1994.

MALDONADO-TORRES, Nelson. Transdisciplinaridade e decolonialidade. Revista Sociedade e Estado, Brasília, v. 31, n. 1, p. 75-97, jan.-abr. 2016.

MONTERO, Paula. Religiões e dilemas da sociedade brasileira. In: MICELI, Sérgio (org.). O que ler na ciência social brasileira (1970-1995). Sumaré: ANPOCS: CAPES, 1999. p. 327-367. (Antropologia, v. 1).

MUSSKOPF, André Sidnei. À meia-luz: a emergência de uma teologia gay. Seus dilemas e possibilidades. Cadernos IHU Ideias, ano 3, n. 32, p. 1-34, 2005. Disponível em: http://www.ihu.unisinos.br/images/stories/cadernos/ideias/o32cadernosihuideias.pdf. Acesso em: 29 abr. 2019.

MUSSKOPF, André Sidnei. Uma brecha no armário: propostas para uma teologia gay. São Paulo: Fonte Editorial, 2015.

MUSSKOPF, André Sidnei. Via(da)gens teológicas: itinerários para uma teologia queer no Brasil. São Paulo: Fonte Editorial, 2012.

NUNES, João Arriscado. O resgate da epistemologia. In: SANTOS, Boaventura de Souza; MENESES, Maria Paula (org.). Epistemologias do Sul. São Paulo: Cortez Editora, 2010. p. 261- 290.

PASSOS, João Déssio; USARSKI, Frank. (org.) Compêndio de Ciência da Religião. São Paulo: Paulinas: Paulus, 2013.

PPG TEOLOGIA PUC-Rio. Histórico. Disponível em: http://www.pos.teo.puc-rio.br/. Acesso em: 19 mar. 2019.

QUERO, Hugo Córdova. Teologia pública e pluralismo religioso: uma questão pendente na agenda sócio-religiosa da América Latina. In: SINNER, Rudolf von; PANOTTO, Nicolás (org.). Teología pública: un debate a partir da América Latina. São Leopoldo: Faculdades EST, 2016. p. 67-76.

QUIJANO, Anibal. Colonialidade do poder e classificação social. In: SANTOS, Boaventura de Souza; MENESES, Maria Paula (org.). Epistemologias do Sul. São Paulo: Cortez Editora, 2010. p. 84-130. 
RIBEIRO, Cláudio de Oliveira. A teologia latino-americana diante do pluralismo religioso: a mudança de lugar teológico a partir das teologias feministas e afro-indígenas.

Encontros Teológicos, Florianópolis, v. 33, p. 309-334, 2018.

RIBEIRO, Cláudio de Oliveira. A teologia latino-americana diante do pluralismo religioso. Horizonte: revista de estudos de teologia e ciências da religião, v. 11, p. 1436-1460, 2013.

RIBEIRO, Cláudio de Oliveira. Ecumenismo, pluralismo e religiões: a busca de novos referenciais teóricos. Revista Eclesiástica Brasileira, Petrópolis, v. 72, p. 651-663, 2012.

RIBEIRO, Cláudio de Oliveira. Pluralismo e religiões: bases ecumênicas para uma teologia das religiões. Estudos de Religião, São Bernardo do Campo, v. 26, p. 209-237, 2012a.

RIBEIRO, Djamila. O que é lugar de fala? Belo Horizonte: Letramento, 2017.

ROSADO-NUNES, Maria José. Teologia feminista e a crítica da razão religiosa patriarcal: entrevista com Ivone Gebara. Revista Estudos Feministas, Florianópolis, v. 14, n. 1, p. 294-304, abr. 2006. Disponível em:

http://www.scielo.br/scielo.php?script=sci_arttext\&pid=S0104026X2006000100016\&ln $\mathrm{g}=\mathrm{en} \& \mathrm{nrm}=$ iso. Acesso em: 29 abr. 2019.

SAMPAIO, Dilaine Soares. Narrativas encantadas que contam história. In: SILVEIRA, Emerson Sena da; SAMPAIO, Dilaine Soares. Narrativas míticas: análise das histórias que as religiões contam. Petrópolis: Vozes, 2018. p. 265-290.

SANTOS, Boaventura de Souza; MENESES, Maria Paula (org.). Epistemologias do Sul. São Paulo: Cortez Editora, 2010.

SENRA, Flávio. Estudos de Ciência(s) da(s) Religião(ões) e Teologia no Brasil: situação atual e perspectivas. Rever, São Paulo, v. 15, n. 2, p. 196-214, jul.-dez. 2015.

SENRA, Flávio. O teólogo e o cientista da religião. Religiografia acerca das interfaces entre Ciências da Religião ou Religiologia e Teologia no Brasil. Rever, São Paulo, v. 16, n. 1, p. 109-136, jan.-abr. 2016.

SENRA, Flávio. Programas profissionais. Situação atual e perspectivas na área de Ciências da Religião e Teologia no Brasil. Reflexus, Vitória, v. 11, n. 18, p. 447-469, 2017.

SILVEIRA, Emerson Sena da (org.). Como estudar as religiões: metodologias e estratégias. Petrópolis: Vozes, 2018.

SILVEIRA, Emerson Sena da. Ciências da religião, perspectivismo ameríndio e hermenêutica: diálogos e interlocuções possíveis. Projeto apresentado para Chamada Pesquisador Visitante (PV) CNPQ e desenvolvido no Programa de Pós-Graduação em Ciências das Religiões da Universidade Federal da Paraíba, 2017. 
SILVEIRA, Emerson Sena da; MORAES JÚNIOR, Manoel Ribeiro. A dimensão teórica dos Estudos da Religião: horizontes histórico, epistemológico e metodológico nas Ciências da Religião. São Paulo: Fonte Editorial, 2017.

SIMAS, Luiz Antonio; RUFINO, Luiz. Fogo no mato: a ciência encantada das macumbas. Rio de Janeiro: Mórula, 2018.

SINNER, Rudolf von. Da Teologia da Libertação para uma teologia da cidadania como teologia pública. Fórum mundial de teologia e libertação. Disponível em: www.wftl.org/pdf/o18.pdf. Acesso em: 19 mar. 2019.

SINNER, Rudolf von. PANOTTO, Nicolás (org.). Teologia pública: um debate a partir da América Latina. São Leopoldo: Faculdades EST, 2016.

SOARES, Afonso Maria Ligório. A "nova” teologia afro-brasileira, a ciência da religião e o ensino religioso. In: OLIVEIRA, Irene Dias de; JORGE, Érika (org.). Teologia afrobrasileira. São Paulo: Arché Editora, 2014. p. 41-54.

SOUZA, Jessé. A elite do atraso: da escravidão a Bolsonaro. Rio de Janeiro: LeYa, 2019.

SOUZA, Jessé. A radiografia do golpe: entenda com o e por que você foi enganado. Rio de Janeiro: LeYa, 2016.

SOUZA, Jessé; BAINBRIDGE, William Sims. Uma teoria da religião. São Paulo: Paulinas, 2008.

STARK, Rodney. O crescimento do cristianismo: um sociólogo reconsidera a história. São Paulo: Paulinas, 2006.

TEIXEIRA, Faustino (org.). A(s) ciência(s) da religião no Brasil. Afirmação de uma área acadêmica. São Paulo: Paulinas, 2001.

UFJF. Projeto político pedagógico. $2^{\circ}$ ciclo do Bacharelado interdisciplinar em Ciências Humanas. Licenciatura em Ciência da Religião e/ou Bacharelado em Ciência da Religião. Instituto de Ciências Humanas - ICH. Departamento de Ciência da Religião, 2011. Disponível em: http://www.ufjf.br/graduacaocre/curso/ppp/. Acesso em: 30 mar. 2019.

USARSKI, Frank. Constituintes da Ciência da Religião: cinco ensaios em prol de uma disciplina autônoma. São Paulo: Paulinas, 2006. (Coleção Repensando a Religião).

USARSKI, Frank. Espectro disciplinar da ciência da religião. São Paulo: Paulinas, 2007.

USARSKI, Frank. História da Ciência da Religião. In: PASSOS, J. D.; USARSKI, F. (org.) Compêndio de Ciência da Religião. São Paulo: Paulinas: Paulus, 2013. p. 51-61. 
VELHO, Otávio. O que a religião pode fazer pelas Ciências Sociais? Religião \& Sociedade, Rio de Janeiro, v. 19, n. 1, p. 9-17, 1998.

VELHO, Otávio. O que a religião pode fazer pelas Ciências Sociais? In: TEIXEIRA, Faustino (org.). A(s) ciência(s) da religião no Brasil: afirmação de uma área acadêmica. São Paulo: Paulinas, 2001. p. 233-250.

VELHO, Otávio. O que a religião pode fazer pelas Ciências Sociais? In: VELHO, Otávio. Mais realistas do que o rei: ocidentalismo, religião e modernidades alternativas. Rio de Janeiro: TopBooks, 2007. p. 247-260.

VIVEIROS DE CASTRO, Eduardo. Metafisicas canibais: elementos para uma antropologia pós-estrutural. São Paulo: Cosac \& Naify, 2015.

VIVEIROS DE CASTRO, Eduardo. Perspectivismo e multinaturalismo na América indígena. O que nos faz pensar? Cadernos do Departamento de Filosofia da PUCRio, Rio de Janeiro, n. 18, v. 1, p. 225-254, set. 2004.

WIRTH, Lauri. Religião e epistemologias pós-coloniais. In: PASSOS, J. D.; USARSKI, F. (org.). Compêndio de Ciência da Religião. São Paulo: Paulinas: Paulus, 2013. p. 129142. 